

Research in Business \& Social Science

IJRBS VOL 8 NO 5 ISSN: 2147-4478

\title{
Influence of continuous quality improvement on patients' satisfaction within hospitals in Nairobi, Kenya
}

\author{
Pamleila Nkirote Ntwiga ${ }^{a *}$, Maina Muchara ${ }^{b}$, Peter Kiriric \\ ${ }^{a, b, c}$ Chandaria School of Business, United States International University, P.O. Box 14634 - 00800, Nairobi, Kenya
}

Crossref

\begin{tabular}{l} 
A R T I C L E IN F O \\
\hline Article history: \\
Received 01 August 19 \\
Received in revs. form 12 August 19 \\
Accepted 04 August 19 \\
\hline Keywords: \\
Continuous quality improvement, \\
Total quality management \\
Patient satisfaction \\
JEL Classification: \\
A11 \\
L22 \\
M10
\end{tabular}

\begin{abstract}
A B S T R A C T
The study examined the influence of implementation of continuous quality improvement (CQI) on patient satisfaction in hospitals within Nairobi. Literature from developed countries indicates that the application of continuous quality improvement has a significant influence on customer satisfaction. However, there is limited literature originating from developing countries. This study aimed at understanding the influence of continuous quality improvements such as Innovativeness, Quality Indicators, Information sharing and Risk management on customer (patient) satisfaction. To reinforce the study, theoretical and empirical review on the CQI and customer (patient) satisfaction was conducted from current and classical literature adopting the total quality management theory of profound knowledge, and the expectation confirmation theory. The mixed research design was used to target employees and patients of hospitals within Nairobi, from whom data was collected through a self-administered questionnaire. Simple random sampling was used to select hospital employees while stratified random sampling was used to select the patients. The questions were placed on a five-point Likert scale. The results of this study showed that innovativeness, information sharing, and risk management significantly influenced patients' satisfaction, while quality indicators had no significant influence on patients' satisfaction. This study, therefore, concluded that continuous quality improvement positively and significantly predicted patients' satisfaction within the hospitals in Nairobi. The study findings guided the researcher to recommend among other things, leaders in the healthcare industry to draw customer satisfaction through the CQI application. Achieved through feedback from the patients and utilizing such information to improve the patient experiences. The researcher proposes that future studies be carried to cut across other industries that were not captured.
\end{abstract}

\section{Introduction}

Quality agenda that is customer driven is ultimate for high performing organization (Talib, Rahman \& Qureshi, 2013). Where quality is meeting or exceeding the expectations of the customer at reasonable cost. Further, Orsini (2013) observed that application of TQM requires a combination of a set of management principles with the right tools and techniques to enable the employees to carry out those management principles in their day to day operation so as to amount to continuous quality improvement. While Zeithaml et al., (2009) defined customer satisfaction as the consumer's response to fulfillment. On the other hand, Deming asserted that quality can only be from the customer point of view and measured through their satisfaction level (Donna, 2012). As suggested by Juran (1995), quality programs should no longer be restricted to manufacturing firms and production units only, but should be adopted into the service industry such as hospitals. However, as observed by Zairi (2013) because of their exceptionality and intricacies, healthcare services have taken longer than other industries to accept quality management programs, concentrating only on stabilization and inspection activities. Further, Rad, Som and Zainuddin (2010) noted that currently health organizations are faced with many challenges such as the need to maintain cost effectiveness of healthcare services, rapid growth of medical technology requirement,

* Corresponding author. ORCID ID: 0000-0001-5667-5339

Peer review under responsibility of Bussecon International Academy.

(C) 2019 Bussecon International. Hosting by SSBFNET- Center for Strategic Studies in Business \& Finance. All rights reserved.

https://doi.org/10.20525/ijrbs.v8i5.473 
and the pressure to improve quality that meets international standards in order to acquire or retain accreditation and most important to surpass customer needs. These challenges have, therefore, forced health leaders to implement systems that can manage health care in an objective and measurable manner to offer a high-quality service, which is the aim of the quality management programs in hospitals that lead to patient's satisfaction (Boiral \& Amara, 2009).

Continuous quality improvement processes within healthcare are established to prevent clinical and administrative problems, increase patient satisfaction, continuously improve the organization's processes, and provide quality healthcare services to the patient (Jong \& Hartog, 2007). However,as Maddern, Maull and Baker (2007) stated that there is need to link the CQI initiatives to customer satisfaction, since there has been limited outcome within the scope as a majority of hospital leaders do not completely comprehend the expected outcome after application of TQM principles within their organizations. This study sought to survey hospitals to determine the influence of continuous quality improvement on patient satisfaction. Various studies on application of TQM principles in hospitals have been done in developed countries, however just a handful have been done in developing countries (Maddern et al., 2007).

Studies conducted on various aspects of TQM within Kenya, however, there is little evidence of research and literature on TQM principles and its influence on customer satisfaction in the Kenyan healthcare sector (Ngware et al., 2016; Awuor and Kinuthia, 2013; Barake, 2015; Wamuyu, 2015). Further, most of the previous studies (Kumar et al., 2009; Kristiano et al., 2012; Sadikoglu \& Olcay 2014; Sara Melo, 2016) are largely theoretical and only few provide empirical evidence to support their conclusions. This study therefore will seek to fill this gap and inform future studies that focus on continuous quality improvement and patient satisfaction in the Kenya Healthcare sector.

\section{Literature Review}

\section{Continuous quality improvement}

Continuous Quality Improvement as Mosedeghrad, (2013) defined, as the process of ensuring that the patient receives right care in the right manner for the right patient within the right environment at the right time by the right person at the right cost to achieve the right results. These "rights" are achieved through incorporating innovations, assessing the involved risks and monitoring the laid down quality indicators. As described by Oakland (2014), continuous quality improvement is a people focused management process that aims at incremental standards in customer satisfaction at a sustainable, affordable cost and an integral part of high-level strategy that operates horizontally across all departments while ensuring that all employees are involved extending to customer. Further, Evans and Lindsay (2013) clarifies that TQM is the process of learning and adapting to continuous changes aimed at organizational success. According to Orsini (2013), CQI is the means to an end, where the end begins with the long-term success of an organization. The Deming theory of profound knowledge is a management philosophy grounded on system theory. Deming (1986) stated that the application of such theory within the organizational systems, that lead to learning the implementation processes that contribute to the continuous improvement of the processes, services, products, employee fulfillment that would result to customer satisfaction.

i. The aspect of CQI according to Oakland (2014)

ii. Innovation as the formation of new ideas that are adopted and executed in processes, products and services (De Jong \& Den Hartog, 2007).

iii. Key performance indicators; which according to Duggirala et al., (2008) quality needs to be measured whether qualitatively or quantitatively. As measurement gives a guide on improvement and enables to determine requirements for change.

iv. Risk management; the process of identifying the effects of uncertainty to the organizational objectives and taking decisions on how to achieve the objectives while mitigating the identified risks (ISO, 2015),

\section{Patient satisfaction}

Customer satisfaction is the degree to which a customer responds to fulfilment of goods or services as defined by Zeithaml et al., 2009. Patient satisfaction is an indicator obtained to compare the patients' expectation of products or services with the perceived performance (Sureshchandar, Rajenran and Anantharaman, 2012). Customer satisfaction is therefore determined by the subjective aspects such as the customer needs, requirements or emotions or it can be determined objectively such as by the feature of the product or the service. This could be construed to mean those aspects of a product that meet or even exceed the needs and expectation of the customer. Zeithaml et al., (2009) elaborated that the expectations of the customer can be defined as either normative standard, which is based on implied relationship between the cost and the reward or based on the performance of the product which could be derived from previous experiences. Thus describing the expectation confirmation theory identified as transaction specific experiences and cumulative experiences (Penchansky \& Thomas, 2008).

\section{Research and Methodology}

The study applied positivism research philosophy as hypotheses were tested. The target population was the hospital employees and patient receiving inpatient care in those hospitals. Simple random sampling was used to select the hospital employee while stratified sampling was used to select the patients. Data was collected using self-administered open and close ended questionnaires for both 
the patients and the employees. Data was then analyzed both descriptive and inferential statistics. Which was then presented in tabular format.

\section{Data analysis}

$\mathrm{Y}=\beta_{0}+\beta_{\mathrm{i}} \mathrm{X}_{\mathrm{i}}+\varepsilon_{\mathrm{i}}$

Where:

$\alpha$ denotes the $\mathrm{y}$ intercept where $\mathrm{x}$ is zero;

$\beta \mathrm{i}$, is regression weight attached to the exogenous variables:

$\varepsilon$ is the error term.

Where;

$\mathrm{Y}=$ Customer (patient)satisfaction

$\mathrm{X}_{\mathrm{i}}=$ Continuous Quality Improvement

Data was further analyzed using both descriptive and inferential statistics. The following assumptions were made in order to make it necessary for a successful regression:

1. Normality Test

2. Linearity Test

3. Multicollinearity Test

4. Homoscedasticity test.

\section{Demographic information}

The response rate for the employees was $83 \%$ while for patients was $60 \%$.

Table 1: Demographic information

\begin{tabular}{llllll}
\hline Demography & Category & Employees & \multicolumn{2}{l}{ Patients } \\
\cline { 3 - 6 } & & Frequency & Percent & Frequency & Percent \\
\hline Gender of Respondents & Male & 69 & $51 \%$ & 43 & $32.1 \%$ \\
\cline { 2 - 6 } & Female & 65 & $49 \%$ & 91 & $67.9 \%$ \\
\cline { 2 - 6 } & Total & $\mathbf{1 3 4}$ & $\mathbf{1 0 0} \%$ & $\mathbf{1 3 4}$ & $\mathbf{1 0 0 . 0} \%$ \\
\hline
\end{tabular}

Age of Respondents

\begin{tabular}{llllll}
\hline Employees & \multicolumn{5}{c}{ Patients } \\
\hline Category & Frequency & Percent & Category & Frequency & Percent \\
\hline $\mathbf{2 5 - 3 4}$ yrs. & 64 & $48 \%$ & under 18 yrs. & 14 & $10.4 \%$ \\
\hline $\mathbf{3 5 - 4 5}$ yrs. & 34 & $25 \%$ & $18-34$ & 67 & $50.0 \%$ \\
\hline $\mathbf{4 5 - 5 4}$ yrs. & 30 & $22 \%$ & $35-44$ yrs. & 24 & $17.9 \%$ \\
\hline Above 55 yrs. & 6 & $4 \%$ & $45-54$ yrs. & 10 & $7.5 \%$ \\
\hline Total & 134 & $100 \%$ & $55-65$ yrs. & 8 & $6.0 \%$ \\
\hline & & Above 65 & 4 & $3.0 \%$ \\
\hline & & Unspecified & 7 & $5.2 \%$ \\
\hline
\end{tabular}

Source: Authors

\section{Influence of continuous quality improvement on patients' satisfaction}

The study sought to establish how continuous quality improvement influenced patients' satisfaction within the hospitals in Nairobi. Continuous quality improvement in the hospitals was determined through four parameters, namely; innovativeness, quality indicators, information sharing, and risk management. The constructs for patient satisfaction were, namely; timeliness of services, cost of service, privacy and confidentiality, and dignity.

The data for the continuous quality improvement variable was analyzed and results presented in table forms. The study used the factor analysis, descriptive statistics and inferential statistics to analyze and present the results. The descriptive statistics used were 
frequencies, mean and standard deviation. The inferential statistics used were correlation coefficients, chi-squared, one-way ANOVA, and multiple linear regression analysis.

\section{Results of factor analysis on continuous quality improvement}

A statistical data reduction and analysis technique that attempts to elucidate correlations among multiple outcomes as the result of one or more basic elucidations or factors is known as factor analysis. The technique entails data reduction, as it endeavors to represent a set of variables by a smaller number. The parameter of continuous quality improvement was measured using sixteen (16) items to produce suitable measures. Factor analysis was conducted on the items to ascertain any correlated parameters with the intention of reducing any unnecessary and redundant data.

Table 2 shows the results of the KMO and Barlett's test for continuous quality improvement. The Kaiser-Meyer-Olkin (KMO) measure of sampling adequacy value associated with continuous quality improvement was 0.972 . The value for the Barlett's test was $x^{2}(120, \mathrm{~N}=268)=8551.568, p<.05$.

Table 2: KMO and Bartlett's test for continuous quality improvement

\begin{tabular}{|c|c|c|}
\hline KMO and Bartlett's Test & & \\
\hline Kaiser-Meyer-Olkin Measur & Adequacy. & .972 \\
\hline Bartlett's Test of Sphericity & Approx. Chi-Square & 9795.992 \\
\hline & $\mathrm{df}$ & 120 \\
\hline & Sig. & 0.000 \\
\hline
\end{tabular}

Source: Authors

The KMO test is used to measure sampling adequacy. When the result shows the KMO value greater than 0.6 , this means that the sample is considered adequate. The result of the KMO test for the parameters of continuous quality improvement was 0.972 . This is greater than 0.6 , therefore, the results reveal that the sample was adequate. The total variance explained by each of the constructs of continuous quality improvement is shown in Table 3. The findings showed that one construct had Eigen values greater than 1.00 and accounted for $89.845 \%$ of the variability in the original variables. The rest of the factors accounted for $10.155 \%$ of the variance.

Table 3: Total variance explained for continuous quality improvement

\begin{tabular}{|c|c|c|c|c|c|c|}
\hline \multicolumn{7}{|c|}{ Total Variance Explained } \\
\hline \multirow[t]{2}{*}{ Component } & \multicolumn{3}{|c|}{ Initial Eigenvalues } & \multicolumn{3}{|c|}{ Extraction Sums of Squared Loadings } \\
\hline & Total & $\%$ of Variance & Cumulative $\%$ & Total & $\%$ of Variance & Cumulative $\%$ \\
\hline 1 & 14.375 & 89.845 & 89.845 & 14.375 & 89.845 & 89.845 \\
\hline 2 & .220 & 1.375 & 91.220 & & & \\
\hline 3 & .190 & 1.188 & 92.408 & & & \\
\hline 4 & .180 & 1.124 & 93.532 & & & \\
\hline 5 & .154 & .963 & 94.495 & & & \\
\hline 6 & .141 & .880 & 95.374 & & & \\
\hline 7 & .128 & .798 & 96.172 & & & \\
\hline 8 & .103 & .641 & 96.814 & & & \\
\hline 9 & .092 & .574 & 97.387 & & & \\
\hline 10 & .085 & .529 & 97.916 & & & \\
\hline 11 & .071 & .442 & 98.359 & & & \\
\hline 12 & .069 & .429 & 98.787 & & & \\
\hline 13 & .061 & .381 & 99.169 & & & \\
\hline 14 & .054 & .336 & 99.505 & & & \\
\hline 15 & .047 & .292 & 99.797 & & & \\
\hline 16 & .033 & .203 & 100.000 & & & \\
\hline
\end{tabular}

Source: Authors 
Figure 1 shows the scree plot for continuous quality improvement. The results showed that one construct had Eigenvalues greater than one.

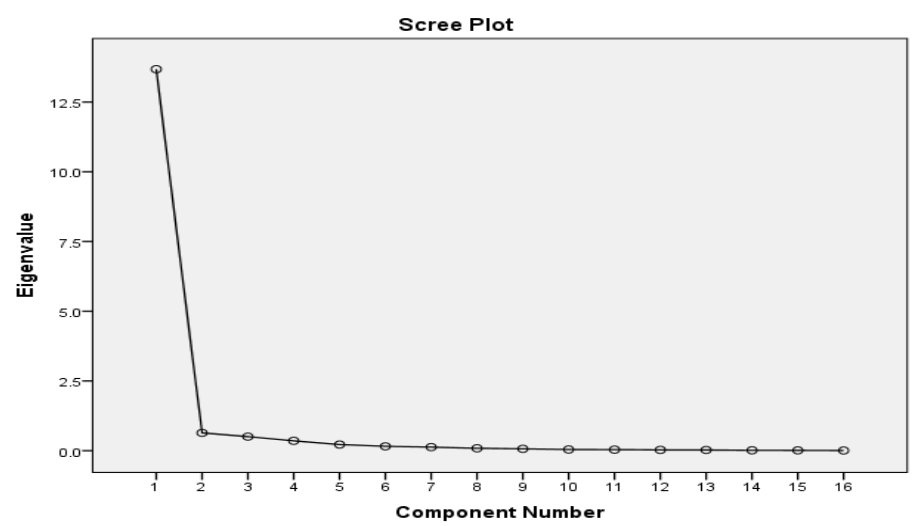

Figure 1: Scree Plot for Eigenvalues for Continuous Quality Improvement

Table 4: Component matrix for continuous quality improvement

\section{Component Matrix ${ }^{a}$}

\begin{tabular}{ll}
\hline & Component \\
\cline { 2 - 2 } & 1 \\
\hline The leadership invest in discovering new and better ways of doing things. & .948 \\
\hline The staff are allowed to experiment new ways of doing things to improve quality & .953 \\
\hline Every department/unit in this hospital has quality indicators that are monitored consistently & .953 \\
\hline All staff use the quality indicators information to make changes that will improve their work. & .952 \\
\hline The staff know how to measure the quality of their work & .933 \\
\hline All hospital staff get all the information pertaining their work on timely basis. & .937 \\
\hline All hospital staff know how the hospital is performing in terms of quality improvement initiatives. & .942 \\
\hline There is always continuity of care to the patient regardless the staff on duty & .950 \\
\hline There is an interactive relationship between staff of the same department while performing their duties & .956 \\
\hline Our Quality improvement teams conduct periodic meetings & .949 \\
\hline The staff pay attention to ensure that there are zero errors in all processes & .951 \\
\hline Precaution about existing or potential or real quality problems are taken & .941 \\
\hline We pay attention to patients' complaints and compliments & .933 \\
\hline Our quality improvement initiative are improved by utilizing statistical techniques & .952 \\
\hline Our quality standards are sufficient for performance improvement & .949 \\
\hline Our quality standards improve our patient experiences & .965 \\
\hline Extraction Method: Principal Component Analysis. & \\
\hline a. l components extracted. &
\end{tabular}

\section{Source: Authors}

The confirmatory factor analysis for continuous quality improvement is shown in Table 4. The results revealed that factor components were above the recommended threshold of 0.6 therefore, no construct was dropped and that all the constructs were included in the model for further analysis. From the results, confirmatory factor analysis showed that continuous quality improvement was adequately sampled for the study with a KMO measure of sampling adequacy of 0.972 .

\section{Findings for descriptive statistics on continuous quality improvement}

Descriptive statistics for continuous quality improvement is presented below. The percentage distribution, mean, and standard deviations were the descriptive statistical tools used.

\section{Percentage (\%) distribution of innovativeness}

Innovativeness is a parameter of continuous quality improvement and its relevance is in the measuring the relationship between continuous quality improvement and patients' satisfaction. The information for innovativeness was sought from investments, experiments, idea generation. On a scale of 1 to 5, (strongly disagree, neutral, agree, and strongly agree), respondents were required to give their opinions on statements relating to the influence of continuous quality improvement on patients' satisfaction. A 
descriptive analysis was conducted to determine the frequency and percentage distribution of the responses. Table 5 shows the frequency distribution of the constructs of continuous quality improvement.

Table 5: Frequency distribution for innovativeness

\begin{tabular}{|c|c|c|c|c|c|}
\hline \multirow[t]{2}{*}{ Constructs } & $\begin{array}{l}\text { Strongly } \\
\text { Disagree }\end{array}$ & Disagree & Neutral & Agree & $\begin{array}{l}\text { Strongly } \\
\text { Agree }\end{array}$ \\
\hline & 1 & 2 & 3 & 4 & 5 \\
\hline $\begin{array}{l}\text { The leadership invests in discovering new and better ways of } \\
\text { doing things. }\end{array}$ & $6.7 \%$ & $15.7 \%$ & $4.5 \%$ & $49.3 \%$ & $23.9 \%$ \\
\hline $\begin{array}{l}\text { The staff are allowed to experiment new ways of doing things } \\
\text { to improve quality }\end{array}$ & $0.7 \%$ & $23.1 \%$ & $3.0 \%$ & $56.7 \%$ & $16.4 \%$ \\
\hline
\end{tabular}

Source: Authors

Regarding the first construct, $6.7 \%$ of the respondents strongly disagreed that their leadership invests in discovering new and better ways of doing things, while $15.7 \%$ of the respondents disagreed with the statement. In addition, the results showed that $4.5 \%$ of the respondents were uncertain, $49.3 \%$ of the respondents agreed that their leadership invests in discovering new and better ways of doing things while $23.9 \%$ of respondents strongly agreed with the statement.

Considering the second construct, $0.7 \%$ of the respondents strongly disagreed that the staff are allowed to experiment new ways of doing things to improve quality, $23.1 \%$ of the respondents disagreed with the statement, $3.0 \%$ of the respondents were uncertain about the statement, $56.7 \%$ of the respondents agreed that the staff are allowed to experiment new ways of doing things to improve quality and $16.4 \%$ of the respondents strongly agreed with the statement.

\section{Percentage distribution of quality indicators}

Quality indicator is the second parameter of this study that measures continuous quality improvement. The study sought information regarding monitoring, performance, information, and measurement. The results in the first construct revealed that none of the respondents strongly disagreed that every department/unit in their hospital has quality indicators that are monitored consistently, $6 \%$ of the respondents disagreed with the statement, $6 \%$ of the respondents were uncertain about the statement, $20.9 \%$ of the respondents agreed that every department/unit in their hospital has quality indicators that are monitored consistently, and $67.2 \%$ of respondents strongly agreed with the statement.

The findings on the second construct show that none of the respondents strongly agreed that all staff use the quality indicators information to make changes that would improve their work, $6 \%$ of the respondents disagreed, $6 \%$ of the respondents were neutral, $34.3 \%$ of the respondents agreed that all staff use the quality indicators information to make changes that will improve their work, and $53.7 \%$ of the respondents strongly consented to the statement.

Considering the third construct, the findings of the study showed that $1.5 \%$ of the respondents strongly disagreed that the staff know how to measure the quality of their work, $6 \%$ of the respondents disagreed with the statement, $9 \%$ of the respondents were uncertain about the statement, $37.3 \%$ of the respondents agreed that the staff know how to measure the quality of their work, and $46.3 \%$ of the respondents strongly agreed with the statement. This is illustrated in Table 6.

Table 6: Frequency distribution for quality indicators

\begin{tabular}{|c|c|c|c|c|c|}
\hline Constructs & $\begin{array}{l}\text { Strongly } \\
\text { Disagree }\end{array}$ & Disagree & Neutral & Agree & $\begin{array}{l}\text { Strongly } \\
\text { Agree }\end{array}$ \\
\hline & 1 & 2 & 3 & 4 & 5 \\
\hline $\begin{array}{l}\text { Every department/unit in this hospital has quality indicators } \\
\text { that are monitored consistently }\end{array}$ & $2.2 \%$ & $20.9 \%$ & $6.0 \%$ & $41.8 \%$ & $29.1 \%$ \\
\hline $\begin{array}{l}\text { All staff use the quality indicators information to make } \\
\text { changes that will improve their work. }\end{array}$ & $0.0 \%$ & $19.4 \%$ & $6.7 \%$ & $53.0 \%$ & $20.9 \%$ \\
\hline The staff know how to measure the quality of their work & $0.7 \%$ & $18.7 \%$ & $9.0 \%$ & $51.5 \%$ & $20.1 \%$ \\
\hline
\end{tabular}

\section{Source: Authors}

\section{Mean and standard deviation on continuous quality improvement}

The fifth objective of the study was to examine how continuous quality improvement influenced patients' satisfaction within the hospital in Nairobi. The respondents were requested to show their level of disagreement or agreement to various statements on a 
Likert scale of 1-5; where 1 showed that they strongly disagreed with the statement, 2 showed that they disagreed with the statements, 3 showed that they were neutral, 4 showed they agreed with the statements and 5 showed that they strongly agreed with the statements. Table 7 revealed the means and standard deviations for the responses to the questions which examined the influence of continuous quality improvement on patients' satisfaction in hospitals within Nairobi.

The findings showed that on average, respondents agreed that the leadership invest in discovering new and better ways of doing things $(M=3.68, S . D=1.193)$, they also agreed that their staff know how to measure the quality of their work $(M=3.72, S . D=$ 1.016). The respondents agreed that their staff pay attention to ensure that there are zero errors in all processes $(M=3.52, S . D=$ $1.109)$, and that they pay attention to patients' complaints and compliments $(M=3.85, S . D=1.114)$.

Table 7: Mean and standard deviation for continuous quality improvement

\begin{tabular}{|c|c|c|c|}
\hline Descriptive Statistics & $\mathbf{N}$ & Mean & $\begin{array}{l}\text { Std. } \\
\text { Deviation }\end{array}$ \\
\hline The leadership invests in discovering new and better ways of doing things. & 134 & 3.68 & 1.193 \\
\hline $\begin{array}{l}\text { The staff are allowed to experiment new ways of doing things to improve } \\
\text { quality }\end{array}$ & 134 & 3.65 & 1.035 \\
\hline $\begin{array}{l}\text { Every department/unit in this hospital has quality indicators that are monitored } \\
\text { consistently }\end{array}$ & 134 & 3.75 & 1.155 \\
\hline $\begin{array}{l}\text { All staff use the quality indicators information to make changes that will } \\
\text { improve their work. }\end{array}$ & 134 & 3.75 & 1.000 \\
\hline The staff know how to measure the quality of their work & 134 & 3.72 & 1.016 \\
\hline All hospital staff get all the information pertaining their work on timely basis. & 134 & 3.51 & 1.129 \\
\hline $\begin{array}{l}\text { All hospital staff know how the hospital is performing in terms of quality } \\
\text { improvement initiatives. }\end{array}$ & 134 & 3.61 & 1.150 \\
\hline There is always continuity of care to the patient regardless the staff on duty & 134 & 3.66 & 1.054 \\
\hline $\begin{array}{l}\text { There is an interactive relationship between staff of the same department while } \\
\text { performing their duties }\end{array}$ & 134 & 3.71 & 1.068 \\
\hline Our Quality improvement teams conduct periodic meetings & 134 & 3.61 & 1.123 \\
\hline The staff pay attention to ensure that there are zero errors in all processes & 134 & 3.52 & 1.109 \\
\hline Precaution about existing or potential or real quality problems are taken & 134 & 3.68 & 1.087 \\
\hline We pay attention to patients' complaints and compliments & 134 & 3.85 & 1.114 \\
\hline $\begin{array}{l}\text { Our quality improvement initiative are improved by utilizing statistical } \\
\text { techniques }\end{array}$ & 134 & 3.68 & 1.080 \\
\hline Our quality standards are sufficient for performance improvement & 134 & 3.81 & 1.022 \\
\hline Our quality standards improve our patient experiences & 134 & 3.72 & 1.030 \\
\hline
\end{tabular}

Source: Author

\section{Correlation between continuous quality improvement and patients satisfaction}

Correlation analysis was conducted to examine the strength of the relationship between continuous quality improvement and patient satisfaction within the hospitals in Nairobi. Table 8 showed that the constructs for continuous quality improvement statistically and significantly correlate with patients' satisfaction. Patients' satisfaction significantly correlates with innovativeness, $r(268)=0.422$, $p<.05$, and quality indicators, $r(268)=0.405, p<.05$. The findings showed that patient satisfaction significantly correlated with information sharing, $r(268)=0.432, p<.05$, and risk management, $r(268)=0.429, p<.05$. The findings also indicated that continuous quality improvement significantly correlated with patients' satisfaction, $r(268)=0.424, p<.05$.

Table 8: Correlation between continuous quality improvement and patient satisfaction

\begin{tabular}{llll}
\hline & Overall Satisfaction & \\
\cline { 2 - 3 } & Pearson Correlation & Sig. (2-tailed) & $\mathrm{N}$ \\
\hline Innovativeness & $.422^{* *}$ & .000 & 268 \\
\hline Quality Indicators & $.405^{* *}$ & .000 & 268 \\
\hline Information Sharing & $.432^{* *}$ & .000 & 268 \\
\hline Risk Management & $.429^{* *}$ & .000 & 268 \\
\hline Continuous Quality Improvement & $.424^{* *}$ & .000 & 268 \\
\hline$* *$ Correlation is significant at the 0.01 level (2-tailed). & & \\
\hline
\end{tabular}

Source: Author 


\section{Chi-squared test on continuous quality improvement}

This study sought to examine if there was a statistically significant association between continuous quality improvement and patients' satisfaction. The findings showed that there was a strong and significant association between continuous quality improvement and patients' satisfaction, $\chi^{2}(2964, N=268)=3523.795, p<.05$. The result of the chi-square is indicated in Table 9 .

Table 9: Chi-squared test on continuous quality improvement

\begin{tabular}{ll}
\hline & Continuous Quality Improvement \\
\hline Pearson Chi-Square & $3523.795^{\mathrm{a}}$ \\
\hline Df & 2964 \\
\hline Asymp. Sig. (2-sided) & .000 \\
\hline$* *$ Correlation is significant at the 0.05 level (2-tailed). & \\
\hline
\end{tabular}

Source: Author

\section{One-way ANOVA on patient satisfaction for continuous quality improvement}

This study sought to conduct a one-way ANOVA test to ascertain whether there were significant differences between the means for patients' satisfaction for continuous quality improvement and the demographic variables of this study; gender of the respondents, age of the respondents, number of hospital beds, type of hospital, and ISO certification.

The findings of this study showed that there were significant differences in the means across respondents' gender, $F(38,229)=$ $38.295, \mathrm{p}<.05$, age, $F(38,229)=18.581, \mathrm{p}<.05$, number of hospital beds, $F(38,229)=23.544, \mathrm{p}<.05$, type of hospitals, $F(38$, $229)=15.388, \mathrm{p}<.05$, and ISO certification, $F(38,229)=44.222, \mathrm{p}<.05$. This is shown in Table 4.10 .

Table 10: One-way ANOVA on patient satisfaction for the continuous quality improvement

\begin{tabular}{|c|c|c|c|c|c|c|}
\hline \multicolumn{7}{|l|}{ ANOVA } \\
\hline & & $\begin{array}{l}\text { Sum } \\
\text { Squares }\end{array}$ & of $\mathrm{df}$ & $\begin{array}{l}\text { Mean } \\
\text { Square }\end{array}$ & $\mathrm{F}$ & Sig. \\
\hline \multirow[t]{3}{*}{ Gender } & Between Groups & 157.899 & 38 & 4.155 & 38.295 & .000 \\
\hline & Within Groups & 24.848 & 229 & .109 & & \\
\hline & Total & 182.746 & 267 & & & \\
\hline \multirow[t]{3}{*}{ Age in Years } & Between Groups & 256.880 & 38 & 6.760 & 18.581 & .000 \\
\hline & Within Groups & 83.314 & 229 & .364 & & \\
\hline & Total & 340.194 & 267 & & & \\
\hline \multirow{3}{*}{$\begin{array}{l}\text { Number of } \\
\text { Hospital beds }\end{array}$} & Between Groups & 775.195 & 38 & 20.400 & 23.544 & .000 \\
\hline & Within Groups & 198.417 & 229 & .866 & & \\
\hline & Total & 973.612 & 267 & & & \\
\hline \multirow{3}{*}{$\begin{array}{l}\text { Type } \\
\text { hospital }\end{array}$} & Between Groups & 167.247 & 38 & 4.401 & 15.388 & .000 \\
\hline & Within Groups & 65.499 & 229 & .286 & & \\
\hline & Total & 232.746 & 267 & & & \\
\hline \multirow{3}{*}{$\begin{array}{l}\text { ISO } \\
\text { Certification }\end{array}$} & Between Groups & 92.854 & 38 & 2.444 & 44.222 & .000 \\
\hline & Within Groups & 12.654 & 229 & .055 & & \\
\hline & Total & 105.507 & 267 & & & \\
\hline
\end{tabular}

Correlation is significant at the 0.05 level (2-tailed).

Source: Author

\section{Regression analysis and hypothesis testing for continuous quality improvement}

This study used the regression model to examine whether process focus explained changes in patients' satisfaction. Various assumptions for regressions were carried out first before conducting the regression analysis.

\section{Assumptions for regression analysis on continuous quality improvement}

The assumptions for regression analysis for continuous quality improvement are presented below. Linearity test, multicollinearity test, homoscedasticity test and normality tests were carried out to examine if assumptions for regression were observed for leadership commitment. 


\section{Linearity test}

The assumption for regression under the linearity test assumes that for a linear relationship to exist, the value for the dependent variable should be a straight-line function of the independent variable. The results showed that the deviation from linearity, $\mathrm{p}$ value $=0.337, P>0.05$. This finding led to a conclusion that the slope of the regression line is different from zero, hence passes the linearity test and that the relationship was linear.

Table 11: Linearity test for continuous quality improvement and patients' satisfaction

\begin{tabular}{|c|c|c|c|c|c|c|c|}
\hline \multicolumn{8}{|l|}{ ANOVA Table } \\
\hline & & & $\begin{array}{l}\text { Sum } \\
\text { Squares }\end{array}$ & $\mathrm{df}$ & $\begin{array}{l}\text { Mean } \\
\text { Square }\end{array}$ & $\mathrm{F}$ & Sig. \\
\hline \multirow{5}{*}{$\begin{array}{l}\text { Overall Satisfaction * } \\
\text { Continuous Quality } \\
\text { Improvement }\end{array}$} & \multirow{3}{*}{$\begin{array}{l}\text { Between } \\
\text { Groups }\end{array}$} & (Combined) & 10.537 & 38 & .277 & 3.948 & .000 \\
\hline & & Linearity & 4.784 & 1 & 4.784 & 68.120 & .000 \\
\hline & & $\begin{array}{l}\text { Deviation } \\
\text { from } \\
\text { Linearity }\end{array}$ & 5.753 & 37 & .155 & 2.214 & .337 \\
\hline & \multicolumn{2}{|c|}{ Within Groups } & 16.082 & 229 & .070 & & \\
\hline & \multicolumn{2}{|l|}{ Total } & 26.619 & 267 & & & \\
\hline
\end{tabular}

\section{Source: Author}

\section{Multicollinearity Test}

The assumption for regression analysis under multicollinearity test assumes that the independent variables should not be highly correlated with each other. The variance inflation factors (VIF) was the statistical tool used to check for multicollinearity in each and every variable. When the VIF values exceed 3, the independent variables are considered to be highly correlated and this is a problem. The findings in Table 12 indicated that the values of the independent variables are all below the threshold of 3. This gives a clear indication that there was no problem with multicollinearity.

Table 12: Multicollinearity test

\begin{tabular}{llll}
\hline Model & \multicolumn{3}{l}{ Collinearity Statistics } \\
\cline { 3 - 3 } & & Tolerance & VIF \\
\hline $\mathbf{1}$ & (Constant) & & \\
\cline { 2 - 3 } & Continuous Quality Improvement & .807 & 1.386 \\
\hline \multicolumn{2}{l}{ a. Dependent Variable: Patient satisfaction from employee perspective }
\end{tabular}

a. Dependent Variable: Patient satisfaction from employee perspective

\section{Source: Author}

\section{Homoscedasticity test}

The notion of homoscedasticity test is to check whether the research data is evenly dispersed from the center. The results indicate the value of the Levene Statistic, $F(92,175)=7.800, p=0.234, p>.05$. The variances are not equal if the significant values are less than 0.05 . The results show that there was equal distribution of population variances hence the variables do not violet the homogeneity of variance assumption needed for an ANOVA. The findings are illustrated in Table 13.

Table 13: Homoscedasticity test for continuous quality improvement

\begin{tabular}{llll}
\hline $\mathrm{F}$ & $\mathrm{df1}$ & $\mathrm{df2}$ & Sig. \\
\hline 1.350 & 38 & 229 & .095 \\
\hline
\end{tabular}

\section{Source: Authors}

\section{Test for normality}

The assumption for regression analysis under normality test requires a normally distribution of the residuals of the model. The findings of this study as shown in Figure 2 depict a histogram of the distribution of the residuals plotted and inspected for normality test. The plot showed that the residuals assumed an inverted U-shape indicating that the data on continuous quality improvement was normally distributed. 


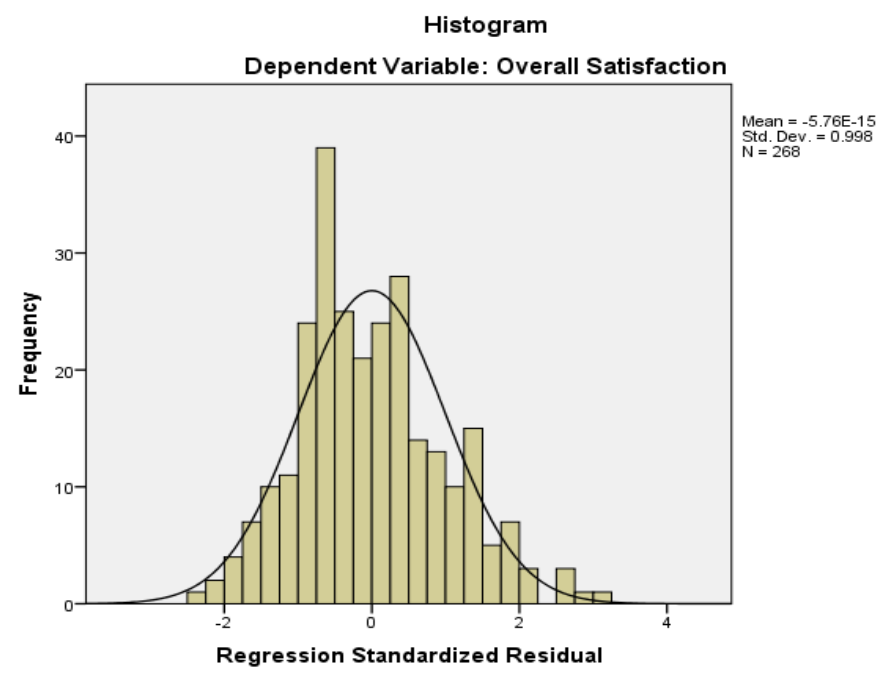

Figure 2: Normality tests for process focus

\section{Regression analysis and hypothesis testing}

A statistical tool that is carried out to examine if one or more independent variables predict the changes in the dependent variable is known as a regression analysis. This study used multiple linear regression analysis to examine the influence of continuous quality improvement on patients' satisfaction within the hospitals in Nairobi. This study tested the null hypothesis:

$\mathbf{H}_{02}$ : Continuous quality improvement does not have a significant influence on patients' satisfaction within the hospitals in Nairobi.

\section{Regression model summary}

From the regression model summary, the findings showed that continuous quality improvement explained $21.7 \%$ variation in patients' satisfaction within the hospitals in Nairobi, $R^{2}=.217$. This implied that $21.7 \%$ of the variations in patients' satisfaction levels within the hospitals in Nairobi could be explained by the continuous quality improvement. Table 14 showed the findings of the regression model.

Table 14: Regression model summary for continuous quality improvement

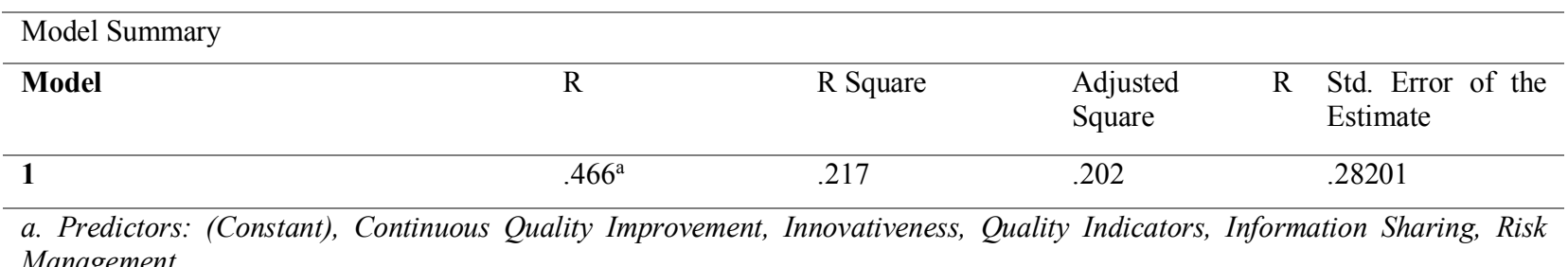
Management

\section{Source: Authors}

\section{Regression ANOVA}

The variability levels in a regression model are tested by the regression ANOVA. It also tests the significance of the model and whether the null hypothesis is rejected or not rejected. The findings are represented in Table 15. From the table, the results showed that the model was statistically significant in linking continuous quality improvement with patients' satisfaction within the hospitals in Nairobi, $F(5,262)=14.542, p<.05$. The null hypothesis that; continuous quality improvement did not have a significant influence on patients' satisfaction within the hospitals in Nairobi was rejected as the value of the F-statistic was not significant.

Table 15: Regression ANOVA for continuous quality improvement

\begin{tabular}{lllllll}
\hline ANOVA $^{\mathrm{a}}$ & & & & \\
\hline Model & Sum of Squares & $\mathrm{df}$ & Mean Square & $\mathrm{F}$ & Sig. \\
\hline $\mathbf{1}$ & & & & & \\
& Regression & 5.783 & 5 & 1.157 & 14.542 & $.000^{\mathrm{b}}$ \\
\cline { 2 - 7 } & Residual & 20.837 & 262 & .080 & & \\
\cline { 2 - 6 } & Total & 26.619 & 267 & & & \\
\hline
\end{tabular}

a. Dependent Variable: Overall Satisfaction

b. Predictors: (Constant), Continuous Quality Improvement, Innovativeness, Quality Indicators, Information Sharing, Risk Management

Source: Authors 


\section{Regression Coefficient}

A regression coefficient is a statistical tool that predicts how the dependent variable changes as a result of a unit change in the independent variable. The multiple linear regression was conducted with an aim of determining the magnitude and direction of the relationship between continuous quality improvement and patients' satisfaction within the hospitals in Nairobi. The findings of this study are presented in Table 16.

Table 16: Regression coefficients for continuous quality improvement

\begin{tabular}{|c|c|c|c|c|c|c|}
\hline \multicolumn{7}{|c|}{ Coefficients $^{\mathrm{a}}$} \\
\hline \multirow{3}{*}{\multicolumn{2}{|c|}{ Model }} & \multirow{2}{*}{\multicolumn{2}{|c|}{ Unstandardized Coefficients }} & \multirow{2}{*}{\multicolumn{3}{|c|}{$\begin{array}{l}\text { Standardized } \\
\text { Coefficients }\end{array}$}} \\
\hline & & & & & & \\
\hline & & $\mathrm{B}$ & Std. Error & Beta & $\mathrm{t}$ & Sig. \\
\hline \multirow[t]{6}{*}{1} & (Constant) & 1.437 & .024 & & 59.707 & .000 \\
\hline & Innovativeness & .109 & .050 & .674 & 2.195 & .029 \\
\hline & Quality Indicators & .070 & .060 & .429 & 1.157 & .248 \\
\hline & Information Sharing & .299 & .098 & 1.785 & 3.067 & .002 \\
\hline & Risk Management & .335 & .113 & 2.031 & 2.954 & .003 \\
\hline & Continuous Quality Improvement & .071 & .009 & .424 & 7.634 & .000 \\
\hline
\end{tabular}

Source: Authors

The results from this study showed that innovativeness, information sharing, and risk management significantly predicted patients' satisfaction, $\beta=0.109, t(268)=2.195, p<.05,05, \beta=0.299, t(268)=3.067, p<.05$ and $\beta=0.335, t(268)=2.954, p<.05$. On the other hand, quality indicators insignificantly predicted patients' satisfaction, $\beta=0.070, t(268)=1.157, p>.05$. From a general point of view, continuous quality improvement significantly predicted patients' satisfaction, $\beta=0.071, t(268)=7.634, p<.05$. The implication of the results is that a unit change in continuous quality improvement would lead to a significant increase in patients' satisfaction within the hospitals in Nairobi by 0.071 units. This study, therefore, concluded that continuous quality improvement positively and significantly predicted patients' satisfaction within the hospitals in Nairobi.

\section{Findings}

The findings of the multiple linear regression analysis established that continuous quality improvement positively and insignificantly predicted patients' satisfaction within the hospitals in Nairobi, $R^{2}=0.217, F(5,262)=14.542, p<.05 ; \beta=0.071, t(268)=7.634, p$ $<.05$. This meant that $21.7 \%$ of the variance in patients' satisfaction within the hospital in Nairobi would be explained by continuous quality improvement. The regression model was also not found to be statistically significant in predicting the relationship between process focus and patients' satisfaction, $F(5,262)=14.542, p<.05$. The multiple linear regression coefficient for continuous quality improvement implied that every unit change in continuous quality improvement predicted 0.071 units change in patients' satisfaction. Pearson value of $p \leq .05$ was adopted by the study and the regression coefficient showed that the $\mathrm{p}$-value of the regression coefficient $(\beta)$ was $p>.05$. This study, therefore, did not reject the null hypothesis and concluded that continuous quality improvement positively and insignificantly influences patients' satisfaction within the hospitals in Nairobi.

The model equation for continuous quality improvement was:

$\mathrm{Y}=\beta_{0}+\beta_{\mathrm{i}} \mathrm{X}_{\mathrm{i}}$

$\mathrm{Y}=1.437+0.071$ continuous quality improvement

The findings of the multiple linear regression analysis established that continuous quality improvement positively and significantly predicted patients' satisfaction within the hospitals in Nairobi. The null hypothesis that continuous quality improvement had no significant influence on patients' satisfaction was therefore rejected. This led to the conclusion that for continuous quality improvement to enhance patients' satisfaction, it should be advocated by committed leaders who would ensure that innovation, monitoring of key performance indicators, information sharing, and risk management are implemented.

\section{Conclusions}

Continuous quality improvement positively and significantly predicted patients' satisfaction within the hospitals in Nairobi. A successful continuous quality improvement needs to identify risks to quality healthcare and provide solution to mitigate those risks. 
These establishments can also adopt the use of statistical analysis to identify the strengths a problem of their systems. Such analysis can yield results that can help the hospitals make informed decisions when dealing with challenges in their establishment. These recommendations are targeted at bettering the environment of the hospital so that the patient can access the best possible quality of healthcare.

This study was based in Nairobi introducing a chance for internal variations of perceptions of patient satisfaction. Other researchers are encouraged to undertake such studies with broader geographical scope. In this regards the researcher suggests that further studies be carried our within other industries and sectors.

\section{References}

Awuor. O. E., \& Kinuthia, D. M. (2013). Total Quality Practices in selected Private Hospitals in Nairobi. European Journal of Business and Management, Vol. 5, No. 13.

Babbie, E. R. (2011). Introduction to social research. Wadsworth Cengage learning.

Barake, M. K. (2015). Influences of Total Quality Management Principles on Quality Health Care Provisions in private Facilities: A case study of Avenue Hospital, Kisumu, Kenya. Retrieved from: erepository.uonbi.ac.ke/handle/11295/92872

Boiral, O. \& Amara, N. (2009). Paradoxes of ISO 9000 performance: a configurational approach.Quality Management Journal, Vol. 16 No. 3, pp. 37-60.

Calvo-Mora, A., Picon, A., Ruiz, C. \& Cauzo, L. (2014). The relationships between soft-hard TQM factors and key business results. International Journal of Operations \& Production Management, Vol. 34 No. 1, pp. 115-143.

Certo, S. C., \& Certo, S. T. (2006). Modern management. Pearson/Prentice Hall.

Dagger, T. S. \& Sweeny, J. S. (2007). Service quality attributes weights: how do short-term and long-term customers construct service quality perceptions? Journal of Service Research, Vol. 10 No. 1, pp. 22-44.

De Jong, J. P., \& Den Hartog, D. N. (2007). How leaders influence employees' innovative behaviour. European Journal of innovation management, 10(1), 41-64.

Deming, W. E. (1986). Out of the crisis. Cambridge, Mass: Massachusetts Institute of Technology, Center for Advanced Engineering Study

Donio, J., Massari, P. \& Passiante Dabho, G. (2006). Customer satisfaction and loyalty in a digital environment: an empirical test. Journal of Consumer Marketing, Vol. 23 No. 7, pp. 445-457.

Donna, S. (2009). Quality (5 $5^{\text {th }}$ Ed.). Pearson Education, Inc.

Duggirala, M., Rajendran, C. \& Anantharaman, R.N. (2008a). Patient-perceived dimensions of total quality service in health care. Benchmarking: An International Journal, Vol. 15 No. 5, pp. 560-583.

Elleuch, A. (2008). Patient satisfaction in Japan. International Journal of Health Care Quality Assurance, Vol. 21 No. 7, pp. 692705.

Evans, J. R., \& Lindsay, W. M. (2013). Managing for quality and performance excellence. Cengage Learning.

Evans, R, J. (2014). Quality Management, Organization, and Strategy. ( $6^{\text {th }}$ Ed.). International edition: South Western.

Fotopoulos, C., Psomas, E. \& Vouzas, F. (2010). Investigating total quality management practice's inter-relationships in ISO 9001:2000 certified organizations. Total Quality Management \& Business Excellence, Vol. 21 No. 5, pp. 503-515.

Gerst, R. M. (2013). Deming's systems thinking and quality of healthcare services: a case study. Leadership in Health Services, Vol. 26 Issue: 3 , pp.204-219

Institute of Medicine (2000). To Err is Human: Building a Safer Health System. ( $1^{\text {st }}$ Ed.). $\quad$ National $\quad$ Academy Press, Washington, DC.

Kristianto, Y., Ajmal, M. M. \& Sandhu, M. (2012). Adopting TQM approach to achieve customer satisfaction. A flour milling company case study. The TQM Journal, Vol. 24 No. 1, pp. 29-46.

Kumar, V., Choisne, F. and Grosbois, D. (2009). Impact of TQM on company's performance. International Journal of Operations \& Production Management, Vol. 26 No. 1, pp. 23-37.

Levine, D. I. \& Toffel, M. W. (2010). Quality management and job quality: how the ISO 9001 standard for quality management systems affects employees and employers. Journal of Management Science, Vol. 56 No. 2, pp. 978-996.

Maddern, H., Maull, R., Smart, A. \& Baker, P. (2007). Customer satisfaction and service quality in UK financial services. International Journal of Operations \& Production Management, Vol. 27 No. 9, pp. 998-1019.

Mosadeghrad. A. M. (2015). Developing and validating a total quality management model for healthcare organizations. The TQM Journal, Vol. 27 Issue: 5, pp.544-564.

Mugenda, O. M., \& Mugenda, A. G. (2012). Research methods dictionary. Nairobi: Applied research and training services.

Ngware, M, W., Wamukuru, D, K. \&, Odebero, S, O. (2006). Total quality management in secondary schools in Kenya: extent of practice. Quality Assurance in Education, Vol. 14 Issue: 4, pp.339-36

O'Connor, E. J. (2010). Keys for successful implementation of total quality management in hospitals. Health Care Management Review, Vol. 35 No. 4, pp. 283-293.

Oakland, J. S. (2014). Total quality management and operational excellence: text with cases. Routledge.

Ochieng, O., Muturi, D., Njihia, N. S. (2015). The impact of ISO 9001 implementation on organizational performance in Kenya. The TQM Journal, Vol. 27 Issue: 6, pp.761-771. 
Orsini, J. N. (2013). The essential Deming: leadership principles from the father of quality. McGraw Hill Professional.

Penchansky, R., \& Thomas, J. (2008). The Concept of Access: Definition and Relationship to Consumer Satisfaction. Medical Care, 19(2), 127-140. Retrieved from http://www.jstor.org/stable/3764310

Pocha, C. (2010). Lean Six Sigma in health care and the challenge of implementation of Six Sigma methodologies at a Veterans Affairs Medical Center. Quality Management in

Rad, N. F., Som, A. P. \& Zainuddin, Y. (2010). Service quality and patients' satisfaction in medical tourism. World Applied Sciences Journal, Vol. 10 No. 1, pp. 24-30.

Sadikoglu, E., \& Olcay, H. (2014). The effects of total quality management practices on performance and the reasons of and the barriers to TQM practices in Turkey. Advances in Decision Sciences, 2014.

Sara Melo, (2016). The impact of accreditation on healthcare quality improvement: a qualitative case study. Journal of Health Organization and Management, Vol. 30 Issue: 8, pp.1242-1258.

Singh, P. J., Power, D. \& Chuong, S.C. (2011). A resource dependence theory perspective of ISO 9000 in managing organizational environment. Journal of Operations Management, Vol. 29 Nos 1-2, pp. 49-64.

Sit, W., Ooi, K., Loke, S. \& Han, G. T. W. (2011). TQM and service quality: a survey of commercial banking industry in Malaysia. International Journal of Services, Economics and Management, Vol. 3 No. 1, pp. 78-91.

Su, Q., Li, Z., Zhang, S.X., Liu, Y. Y. \& Dang, J. X. (2008). The impacts of quality management practices on business performance. An empirical investigation from China. International Journal of Quality and Reliability Management, Vol. 25 No. 8, pp. 809-823.

Sureshchandar, G. S., Rajendran, C. \& Anantharaman, R. N (2002). The relationship between service quality and customer satisfaction - a factor specific approach. Journal of Services Marketing, Vol. 16 Issue: 4, pp.363-379.

Talib, F., Rahman, Z. \& Qureshi, M. N. (2013). An empirical investigation of relationship between total quality management practices and quality performance in Indian service companies. International Journal of Quality \& Reliability Management, Vol. 30 No. 3, pp. 280-318.

Van Urden, C. J., Ament, A. J., et al. (2014). Patient satisfaction with an out-of-hours primary care in the Netherlands. BMC Health Services. 2005 Jan 5.

Wamuyu, M. G. (2015). Total Quality Management in Kenya's Healthcare Industry. (Thesis for Master's Degree University of Nairobi).

Wu, H. L., Liu, C. H. \& Hsu, W. H. (2008). An integrative model of customers' perceptions of health care services in Taiwan. The Service Industries Journal, Vol. 28 No. 9, pp. 1307-1319.

Zairi, M. (2013). The TQM legacy - gurus' contributions and theoretical impact. The TQM Journal, Vol. 25 No. 6, pp. 659-676.

Zeithaml, V. A., Bitner, M. J.and Gremler, D. D. (2009). Services Marketing: Integrating Customer Focus across the Firm. (5 ${ }^{\text {th }}$ Ed.). New York: McGraw-Hill. 